\title{
KOMPETENSI GURU PEMBIMBING KHUSUS DENGAN PENGAJARAN KOLABORATIF
}

\author{
Tita Rosita \\ IKIP Siliwangi \\ Yuyus Suherman \\ Universitas Pendidikan Indonesia
}

Abstract: The purpose of this study is to analyze the competence of special education teacher with collaborative teaching. The research method used is qualitative research that is literature study (library research). Based on the results of the literature study, it is found that collaborative teaching can develop the competence of Special Supervising Teachers in the area of specific abilities, namely the abilities needed to educate students of specific types of special needs. As for collaborative teaching, special education teacher can develop individual education programs that function as blueprints for special education programs.

Keywords: Competency of special tutor teachers (GPK), collaborative teaching.

Abstrak: Penelitian ini bertujuan untuk menganalisis kompetensi Guru Pembimbing Khusus dengan pengajaran kolaboratif. Metode penelitian yang digunakan yaitu penelitian kualitatif yang bersifat studi pustaka (library research). Berdasarkan hasil studi pustaka diperoleh gambaran bahwa pengajaran kolaboratif dapat mengembangkan kompetensi Guru Pembimbing Khusus pada area specific ability yaitu kemampuan yang diperlukan untuk mendidik peserta didik kebutuhan khusus jenis tertentu. Adapun dari pengajaran kolaboratif GPK dapat mengembangkan program pendidikan individual yang berfungsi sebagai cetak biru untuk program pendidikan khusus.

Kata Kunci: Kompetensi guru pembimbing khusus (GPK), pengajaran kolaboratif.

\section{A. PENDAhULUAN}

Banyak orang tua dari anak-anak penyandang disabilitas tidak percaya bahwa kebutuhan anak-anak mereka dapat dipenuhi dalam pendidikan umum. Keyakinan bahwa anak mereka tidak akan berhasil dalam pendidikan umum didasarkan pada kasus sebagian besar pendidik menganut konsep inklusif, namun secara pragmatis banyak yang menentang praktik yang sebenarnya. Sehingga saat ini masih ada perlawanan dan keengganan dari pihak guru dan administrator terhadap implementasi pendidikan inklusif. Terlepas dari pilihan orang tua, sekolah memiliki kewajiban hukum untuk memastikan bahwa siswa penyandang disabilitas memiliki kesempatan untuk dididik di samping anakanak tanpa disabilitas. 


\section{Tita Rosita, Yuyus Suherman}

Individuals with Disabilities Education Act Amandements (IDEA) tahun 1997 mengamanatkan bahwa siswa penyandang disabilitas memiliki akses ke pendidikan umum, sistem sekolah dan guru berkewajiban untuk menggunakan praktik pendidikan yang membedakan konten, instruksi, dan penilaian sehinggasetiap anak dapat sukses dalam pendidikan umum. Berdasarkan IDEA, teknis pelaksaan pendidikan untuk anak disabilitas di Indonesai diatur dalam Permendiknas terkait dengan pendidikan inklusif.

Pendidikan inklusif menurut Pasal 1 Peraturan Menteri Pendidikan Nasional (Permendiknas) No. 70 Tahun 2009 yaitu sistem penyelenggaraan pendidikan yang memberikan kesempatan kepada semua peserta didik yang memiliki kelainan dan memiliki potensi kecerdasan dan/atau bakat istimewa untuk mengikuti pendidikan atau pembelajaran dalam satu lingkungan pendidikan secara bersama-sama dengan peserta didik pada umumnya.

Salah satu kriteria pendidikan inklusif yaitu terdapat Guru Pembimbing Khusus atau GPK (Pedoman Umum Penyelenggaraan Pendidikan Inklusif 2007: 29). Guru Pembimbing Khusus adalah guru yang memiliki kualifikasi /latar belakang Pendidikan Luar Biasa (PLB) yang bertugas menjembatani kesulitan Anak Berkebutuhan Khusus $(\mathrm{ABK})$ dan guru kelas atau mata pelajaran dalam proses pembelajaran serta melakukan tugas khusus yang tidak dilakukan oleh guru pada umumnya.

Berdasarkan hasil temuan dari penelitian Siswati, B. (2012) bahwa GPK masih kurang kompeten dalam menjalankan tugasnya dilihat dari sisi task achievement; kurang kompeten ketika melaksanakan tugas mengadakan pelatihan persiapan dan penelitian pengembangan pendidikan inklusif. Hasil penelitian Prita Indriawati (2013) juga menunjukkan bahwa pelaksanaan program kekhususan pada pendidikan inklusif ada beberapa kendala, diantaranya yaitu Guru Pembimbing Khusus (GPK) kurang memahami konsep penyusunan Program Pembelajaran Individual (PPI), keterbatasan waktu dan tenaga Guru Pembimbing Khusus (GPK), dan masih adanya bias pemahaman tentang konsepsi pendidikan inklusif, khususnya dalam merancang dan melaksanakan program kekhsususan.

Berdasarkan penelitian di atas, Guru Pembimbing Khusus (GPK) perlu kompetensi yang dikembangkan untuk mewujudkan penyusunan Program Pembelajaran Individual dengan berkolaborasi untuk mengembangkan cara-cara inovatif untuk menggabungkan teknik pengajaran baru. Menurut Weiner (2003:12) guru perlu menumbuhkan hal-hal seperti: (1) belajar dari pengalaman secara terus-menerus; (2) melakukan refleksi; (3) melakukan teoritisasi tentang bagaimana yang terbaik untuk 
menemukan kebutuhan siswa, baik secara individual maupun secara kolektif; (4) belajar melalui kolaborasi dengan kolega secara terus menerus.

Untuk mencapai tujuan pengembangan pendidikan inklusi, kolaborasi perlu bantuan profesional lain selain guru pembimbing khusus yaitu profesional kesehatan seperti ahli fisioterapi, wicara dan terapis bahasa, serta terapis okupasi (Hemmingsson, Gustavsson, dan Townsend 2007). Adapun dalam konteks inklusi tujuan kolaborasi adalah untuk memberikan peluang bagi siswa penyandang disabilitas untuk menjadi anggota komunitas mereka yang bermakna. Untuk kolaborasi yang baik, penting untuk mengetahui karakteristik dan kompetensi profesional satu sama lain, memiliki gaya komunikasi yang efektif (baik formal maupun informal) dan memiliki hubungan kerja dan pribadi yang positif.

Saat kolaborasi berlangsung, anggota tim belajar memecahkan berbagai masalah bersama dan tumbuh individu sebagai tim profesional (Villeneuve dan Hutchinson 2012). Namun demikian dalam pelaksanaanya, banyak hambatan untuk kolaborasi dalam pendidikan inklusif. Hambatan dalam kolaborasi yaitu (1) ambiguitas mengenai peran dan tanggung jawab (Hemmingsson, Gustavsson, dan Townsend 2007); (2) profesional yang tidak mengalami satu sama lain sebagai mitra yang setara dan sering memiliki latar belakang teoretis dan filosofis yang berbeda karena dididik dan dipekerjakan dalam sistem yang berbeda (Bose dan Hinojosa 2008; Silverman dan Millspaugh 2006);(3) hambatan organisasi (Hemmingsson, Gustavsson, dan Townsend 2007) dan(4) kurangnya waktu untuk komunikasi formal (Bose dan Hinojosa 2008; Nochajski 2002).

\section{B. METODE}

Penelitian ini adalah penelitian kualitatif yang bersifat studi pustaka (library research) yang menggunkan buku-buku dan literatur-literatur lainnya sebagai objek yang utama (Hadi, 1995: 3). Jenis penelitian yang digunakan adalah kualitatif, yaitu penelitian yang menghasilkan informasi berupa catatan dan data deskriptif yang terdapat di dalam teks yang diteliti (Mantra, 2008: 30). Dengan penelitian kualitatif, perlu dilakukan analisis deskriptif. Metode analisis deskriptif memberikan gambaran dan keterangan yang secara jelas, objektif, sistematis, analitis dan kritis. Adapun tujuan penelitian ini yaitu untuk menganalisis kompetensi guru pendamping khusus (GPK) dengan pengajaran kolaboratif. 


\section{HASIL PEMBAHASAN}

\section{Kompetensi Guru Pendamping Khusus (GPK)}

Guru Pembimbing Khusus adalah guru yang memiliki kualifikasi /latar belakang Pendidikan Luar Biasa (PLB) yang bertugas menjembatani kesulitan Anak Berkebutuhan Khusus (ABK) dan guru kelas/mapel dalam proses pembelajaran serta melakukan tugas khusus yang tidak dilakukan oleh guru pada umumnya. Namun dalam pedoman Tendik tahun 2007 menyatakan bahwa perekrutan GPK terdapat tiga alternatif yaitu pertama, melalui kerjasama guru SLB terdekat; kedua, merekrut guru dengan kualifikasi PLB dan guru reguler yang memperoleh pelatihan tentang ABK dan ketiga, dari klinik-klinik pendidikan atau pusat pengembangan anak, sehingga di lapangan muncul beragam kualifikasi yang berbeda-beda menjadi GPK.

Kompetensi GPK selain dilandasi oleh empat kompetensi guru yang utama (pedagogik, kepribadian, profesional, dan sosial), secara khusus juga berorientasi pada tiga kemampuan utama (Depdiknas, 2007), yaitu:

- Kemampuan umum (general ability) adalah kemampuan yang diperlukan untuk mendidik peserta didik pada umumnya (anak normal).

- Kemampuan dasar (basic ability) adalah kemampuan yang diperlukan untuk mendidik peserta didik berkebutuhan khusus.

- Kemampuan khusus (specific ability) adalah kemampuan yang diperlukan untuk mendidik peserta didik kebutuhan khusus jenis tertentu (spesialis).

Adapun tugas Guru Pembimbing Khusus (GPK) antara lain adalah:

1) Menyusun instrumen asesmen pendidikan bersama-sama dengan guru kelas dan guru mata pelajaran,

2) Membangun sistem koordinasi antara guru, pihak sekolah dan orang tua peserta didik,

3) Melaksanakan pendampingan ABK pada kegiatan pembelajaran bersama-sama dengan guru kelas/guru mata pelajaran/guru bidang studi,

4) Memberikan bantuan layanan khusus bagi anak-anak berkebutuhan khusus yang mengalami hambatan dalam mengikuti kegiatan pembelajaran di kelas umum, berupa remidi ataupun pengayaan,

5) Memberikan bimbingan secara berkesinambungan dan membuat catatan khusus kepada anak-anak berkebutuhan khusus selama mengikuti kegiatan pembelajaran, yang dapat dipahami jika terjadi pergantian guru, 
6) Memberikan bantuan (berbagi pengalaman) padaguru kelas dan/atau guru mata pelajaran agar mereka dapat memberikan pelayanan pendidikan kepada anak-anak berkebutuhan khusus.

\section{Pengajaran Kolaboratif}

\section{a. Definisi Kolaborasi}

Kata kolaborasi berasal dari bahasa Latin collabre, yang berarti bekerja sama atau bekerja bersama (Welch \& Sheridan, 1995). Kolaborasi adalah proses yang dapat terjadi pada berbagai tingkatan atau tingkatan dan pengaturan. Durasi kolaborasi mungkin dalam jangka panjang dalam beberapa kasus, sedangkan dalam kasus lain mungkin hanya berlangsung beberapa menit. Misalnya, dua guru bekerjasama dalam pengajaran di kelas atau seorang guru kelas bisa berkonsultasi dengan spesialis (Psikolog atau Terapis) untuk mempelajari strategi pengajaran spesifik atau metode adaptasi pengajaran.

\section{b. Tujuan Kolaborasi}

Robbins (1990) mengungkapkan bahwa kolaborasi dapat dianggap sebagai membuat keputusan untuk mencapai beberapa jenis tujuan bersama untuk menyelesaikan masalah. Adapun pengambilan keputusan dalam kolaborasi melibatkan dua keterampilan penting yaitu pemecahan masalah dan komunikasi. Jayanthi and Friend (1992) mengidentifikasi lima tahap umum dalam pemecahan masalah, yaitu (a) mengidentifikasi masalah, (b) menghasilkan solusi yang memungkinkan, (c) memutuskan rencana aksi, (d) mengimplementasikan solusi, dan (e) mengevaluasi hasil.

Komunikasi selama pengambilan keputusan dan pemecahan masalah membutuhkan keterampilan komunikasi interpersonal yang efektif. Komunikasi adalah proses timbal balik untuk mengirim dan menerima pesan, baik verbal maupun nonverbal, seperti bahasa tubuh, ekspresi wajah, dan kontak mata. Kunci komunikasi adalah bahwa pesan diinterpretasikan dengan benar. Cara sederhana untuk mengetahui bagaimana seseorang mengirim dan menerima pesan adalah dengan memonitor komunikasi seseorang menggunakan akronim CAPS (Welch \& Sheridan, 1995), yang merupakan singkatan dari clarifying, attending, paraphrasing, and summarizing. 
Tita Rosita, Yuyus Suherman

\section{c. Bentuk-bentuk kolaborasi}

Bentuk-bentuk kolaborasi diantaranya yaitu pengajaran tim, konsultasi kolaboratif, tim intervensi, dan tim pemberian layanan siswa multidisiplin.

\section{1) Pengajaran tim (team teaching)}

Team teaching yaitu dua guru atau lebih bekerja bersama di kelas yang sama, berbagi tanggung jawab bersama untuk pengajaran (Bauwens \& Hourcade, 1995). Team teaching memiliki banyak keunggulan (Welch \& Sheridan, 1995), diantaranya yaitu pertama, mengurangi rasio guru-murid di kelas; kedua, instruksi individual untuk siswa berkebutuhan khusus lebih layak dilakukan dengan dua guru; ketiga, pengajaran tim memungkinkan pendidik kesempatan untuk mengembangkan keterampilan profesional mereka sendiri dengan belajar dari satu sama lain.

Namun demikian, keseimbangan dalam proses pengajaran pendidik umum lebih mendominasi, sehingga yang terjadi guru pembimbing khusus tampaknya kurang bertanggung jawab (Embury dan Kroeger 2012; Harbort et al. 2007). Implikasi dari hal tersebut menunjukkan bahwa pembimbing khusus lebih sering berada sebagai peran pendukung dalam kelas yang diajarkan bersama (Harbort et al. 2007; Scruggs, Mastropieri, dan McDuffie 2007). Bahkan penelitian yang melibatkan siswa mengungkapkan persepsi bahwa guru pembimbing khusus adalah penolong (Bessette 2008).

Oleh karena itu perlu adanya pedoman dalam pengajaran tim. Beberapa pedoman dasar untuk pengajaran tim dapat membantu memastikan kesuksesan (Bauwens \& Hourcade, 1995; Brann, Loughlin, \& Kimball, 1991; Gelzheiser \& Meyers, 1990; Nowacek, 1992; Walther-Thomas, Bryant, \& Land, 1996; Welch \& Sheridan, 1995). Pertama, mulailah dari yang kecil yaitu dengan mengidentifikasi bidang mata pelajaran, kelompok siswa dan alokasikan jumlah waktu tertentu seperti 1 jam sehari untuk pengajaran tim. Kedua, memiliki tujuan khusus, seperti keterampilan berekspresi tertulis dalam seni bahasa, sebagai bidang topik untuk pengajaran tim. Kemudian tentukan beberapa jenis kriteria terukur yang akan membantu untuk mengidentifikasi apa yang ingin dicapai oleh siswa di akhir upaya pengajaran tim. Dengan cara ini, para guru mengumpulkan data akademik dan sikap yang akan membantu mereka dalam mengevaluasi kolaborasi mereka. Ketiga, sisihkan minimal 30 menit seminggu untuk perencanaan, baik di awal atau akhir minggu. Selama pertemuan perencanaan, harus mempertimbangkan dengan cermat siapa yang akan melakukan selama 
pengajaran tim untuk setiap hari dalam minggu berikutnya. Keempat, tentukan dengan cermat peran dan tanggung jawab masing-masing guru dengan menjawab pertanyaan-pertanyaan seperti berikut: Apakah satu atau kedua guru akan mengembangkan rencana pelajaran? Akankah kedua guru berbagi tugas pengajaran untuk siswa berkebutuhan khusus maupun dengan siswa yang tidak memiliki kebutuhan khusus? Apa kriteria dan prosedur evaluasi? Akankah penilaian dan evaluasi dibagi, atau menjadi tanggung jawab satu guru? Apakah siswa akan dibagi menjadi beberapa kelompok? Adaptasi seperti apa yang akan dibuat untuk siswa berkebutuhan khusus dan oleh siapa? Kelima, mengidentifikasi potensi masalah atau tantangan yang mungkin timbul, terutama untuk anak-anak dengan kebutuhan khusus. Di sini, latar belakang dan keahlian spesialis memainkan peran penting dalam proses perencanaan. Terakhir, jelajahi bagaimana untuk mengevaluasi upaya tim. Untuk melakukannya, dapat dilihat data kinerja siswa atau survei kepuasan siswa dan orang tua.

\section{2) Konsultasi kolaboratif}

Konsultasi didefinisikan sebagai proses penyelesaian masalah di mana dua orang konsultan atau lebih terlibat dalam upaya untuk memberi manfaat kepada seorang klien atau lebih yang menjadi tanggung jawab mereka dalam konteks tertentu (Curtis \& Meyers, 1988, hlm. 36). Bentuk konsultasi kolaboratif yaitu rencana aksi yang menguraikan tujuan, peran, tanggung jawab, garis waktu tertentu, dan kriteria evaluasi.

\section{3) Tim intervensi}

Tim intervensi terdiri dari pendidik yang bertemu secara berkala untuk membahas perkembangan perilaku atau akademik seorang siswa yang belum menerima layanan dukungan pendidikan khusus. Tujuan dari tim ini adalah untuk meminimalkan jumlah rujukan yang tidak tepat untuk pendidikan khusus dengan mengembangkan dan mengimplementasikan intervensi melalui layanan tidak langsung untuk memenuhi kebutuhan khusus siswa dalam pengaturan ruang kelas (Graden, Casey, \& Christenson, 1985).

\section{4) Tim pengiriman layanan siswa multidisiplin}

Tim pengiriman layanan siswa multidisiplin (Multidisciplinary Student Service Delivery (MSSD) terdiri dari guru, administrator, spesialis, dan orang tua. Tim ini meninjau berbagai data penilaian formal dan informal untuk menentukan apakah seorang siswa memenuhi syarat untuk program pendidikan khusus. 
Tita Rosita, Yuyus Suherman

Setelah kelayakan ditetapkan, tim mengembangkan program pendidikan individual/ Individualized Education Program (IEP) yang terdiri dari tujuan dan prosedur khusus untuk mencapai tujuan. IEP berfungsi sebagai cetak biru, menguraikan siapa yang akan menyediakan layanan khusus untuk memenuhi tujuan dan di mana layanan tersebut akan dikirimkan. Proses pengambilan keputusan dari tim MSSD (Multidisciplinary Student Service Delivery) bersifat kolaboratif.

Praktik inklusi didasarkan pada tanggung jawab bersama atas pemberian layanan dalam berbagai pengaturan. Dengan mengingat prinsip ini, pendidik harus menganggap pendidikan khusus sebagai layanan, bukan sebagai tempat. Dengan demikian, peran pembimbing khusus (GPK) dapat direkonseptualisasikan sebagai koordinator IEP (Individualized Education Program), bukan sebagai penyedia layanan tunggal. Hal ini dikarenakan IEP berfungsi sebagai alat untuk merencanakan dan mengimplementasikan layanan dalam berbagai pengaturan, penting bagi semua pemangku kepentingan untuk memainkan peran yang berarti dalam pengembangannya.

Berdasarkan beberapa kajian penelitian terkait dengan kompetensi Guru Pembimbing Khusus (GPK) bahwa pembimbing khusus lebih sering berada sebagai peran pendukung dalam kelas yang diajarkan bersama (Harbort et al. 2007; Scruggs, Mastropieri, dan McDuffie 2007), kemudian siswa mengungkapkan persepsinya bahwa guru pembimbing khusus adalah penolong (Bessette 2008). Adapun hasil penelitian Siswati, B. (2012) bahwa GPK masih kurang kompeten dalam menjalankan tugasnya dilihat dari sisi task achievement. Hal ini diperkuat oleh hasil penelitian Prita Indriawati (2013) juga yang menunjukkan bahwa Guru Pembimbing Khusus (GPK) kurang memahami konsep penyusunan Program Pembelajaran Individual (PPI). Oleh karena itu Guru Pembimbing Khusus (GPK) perlu kompetensi yang dikembangkan untuk mewujudkan penyusunan Program Pembelajaran Individual dengan berkolaborasi untuk mengembangkan cara-cara inovatif untuk menggabungkan teknik pengajaran baru yaitu dengan pengajaran kolaboratif.

Untuk mencapai tujuan ini, kolaborasi perlu bantuan profesional lain selain guru pembimbing khusus yaitu profesional kesehatan seperti ahli fisioterapi, wicara dan terapis bahasa, serta terapis okupasi (Hemmingsson, Gustavsson, dan Townsend 2007). Adapun pengambilan keputusan dalam kolaborasi melibatkan dua keterampilan penting yaitu pemecahan masalah dan komunikasi. Jayanthi and Friend (1992) mengidentifikasi lima 
tahap umum dalam pemecahan masalah, yaitu (a) mengidentifikasi masalah, (b) menghasilkan solusi yang memungkinkan, (c) memutuskan rencana aksi, (d) mengimplementasikan solusi, dan (e) mengevaluasi hasil.

Kolaborasi dapat dilakukan oleh Guru Pembimbing Khusus yaitu dengan pengajaran tim, konsultasi kolaboratif, tim intervensi, dan tim pemberian layanan siswa multidisiplin. Pengajaran tim yaitu dua guru atau lebih bekerja bersama di kelas yang sama, berbagi tanggung jawab bersama untuk pengajaran (Bauwens \& Hourcade, 1995). Konsultasi kolaboratif yaitu rencana aksi yang menguraikan tujuan, peran, tanggung jawab, garis waktu tertentu, dan kriteria evaluasi. Tim intervensi bertujuan untuk meminimalkan jumlah rujukan yang tidak tepat. Adapun tim pengiriman layanan siswa multidisiplin (Multidisciplinary Student Service Delivery) yaitu terdiri dari guru, administrator, spesialis, dan orang tua; tim ini meninjau berbagai data penilaian formal dan informal untuk menentukan apakah seorang siswa memenuhi syarat untuk program pendidikan khusus.

\section{KESIMPULAN}

Kompetensi Guru Pembimbing Khusus (GPK) selain dilandasi oleh empat kompetensi guru yang utama (pedagogik, kepribadian, profesional, dan sosial), secara khusus juga berorientasi pada kemampuan khusus (specific ability). Kemampuan khusus adalah kemampuan yang diperlukan untuk mendidik peserta didik kebutuhan khusus jenis tertentu (spesialis). Untuk meningkatkan kompetensi kemampuan khusus GPK, perlu adanya pengembangan kompetensi dengan melakukan pengajaran kolaboratif.

Kolaborasi dapat dilakukan oleh Guru Pembimbing Khusus yaitu dengan pengajaran tim, konsultasi kolaboratif, tim intervensi, dan tim pemberian layanan siswa multidisiplin. Sehingga dengan kolaborasi dapat memberikan penilaian formal dan informal untuk menentukan apakah seorang siswa memenuhi syarat untuk program pendidikan khusus, serta dapat menetetapkan kelayakan untuk mengembangkan program pendidikan individual (PPI) yang berfungsi sebagai cetak biru untuk program pendidikan khusus.

\section{DAFTAR PUSTAKA}

Bauwens, J., \& Hourcade, J. J. (1995). Cooperative teaching: Rebuilding the schoolhouse for all students. Pro-Ed, 8700 Shoal Creek Blvd., Austin, TX 78757-6897. 
Bessette, Harriet J. (2008). "Using Students' Drawings to Elicit General and Special Educators Perceptions of Co-Teaching." Teaching and Teacher Education 24 (5): 1376-1396. doi:101016/j.tate.2007.06.007.

Curtis, M. J., \& Meyers, J. (1988). Consultation: A foundation for alternative services in the schools. Alternative educational delivery systems: Enhancing instructional options for all students, 35-48.

Bose, P., and J. Hinojosa. (2008). "Reported Experiences from Occupational Therapists Interacting with Teachers in Inclusive Early Childhood Classrooms." American Journal of Occupational Therapy 62(3): 289-297.

Depdiknas (2007). Pedoman Khusus Penyelenggaraan Pendidikan Inklusif tentang Pengadaan dan Pembinaan Tenaga Pendidik. Jakarta: Direktorat Pembinaan Sekolah Luar Biasa.

Embury, D. C., \& Kroeger, S. D. (2012). Let's Ask the Kids: Consumer Constructions of Co-Teaching. International Journal of Special Education, 27(2), 102-112.

Harbort, Gina, Philip L. Gunter, Karla Hull, Queen Brown, Martha L. Venn, Larry P. Wiley, and Ellen W. Wiley. 2007. "Behaviors of Teachers in Co-Taught Classes in a Secondary School.” Teacher Education and Special Education: The Journal of the Teacher Education Division of the Council for Exceptional Children 30 (1): 13-23. doi:10.1177/088840640703000102.

Harjaningrum, Agnes Tri. (2007). Peranan Orang Tua dan Praktisi dalam Membantu Tumbuh Kembang Anak Berbakat Melalui Pemahaman dan Tren Pendidikan. Jakarta: Prenada Media Group.

Hemmingsson, H., A. Gustavsson, and E. Townsend. (2007). "Students with Disabilities Participating in Mainstream Schools: Policies that Promote and Limit Teacher and Therapist Cooperation.” Disability \& Society 22 (4): 383-398.

Indriawati, Prita. (2013). Implementasi Kebijakan Tugas Guru Pembimbing Khusus pada Pendidikan Inklusif di SD Negeri se-Kecamatan Junrejo Batu. Jurnal Kebijakan dan Pengembangan Pendidikan. Vol. 1, Nomor 1 Januari 2013,49-55 ISSN: 23377623; EISSN: 2337-7615

Nochajski, S. M. (2002). "Collaboration Between Team Members in Inclusive Educational Settings." Occupational Therapy in Health Care 15 (3-4): 101-112. doi:10.1080/J003v15n03_06.

Peraturan Menteri Pendidikan Nasional Republik Indonesia Nomor 70.2009. Pendidikan Inklusif Bagi Peserta Didik Yang Memiliki Kelainan Dan Memiliki Potensi Kecerdasan Dan/Atau Bakat Istimewa.

Silverman, F. L., and R. Millspaugh. (2006). "Physical Proximity of Occupational Therapy and Learning Support Instruction: How Room Sharing Can Promote Collaboration for Professionals and Success for Students." Teaching Exceptional Children Plus 2 (4): Article 2. 
Siswati, B. (2012). Kompetensi Guru Pembimbing Khusus (Gpk) Pada Resource Center Pendidikan Inklusif "X" Di Kota Bandung Menurut Perspektif Kepala Sekolah, Guru, Dan Orang Tua: Studi Fenomenologi Di SMP Negeri "Y" (Universitas Pendidikan Indonesia).

Villeneuve, M., and N. L. Hutchinson. (2012). "Enabling Outcomes for Students with Developmental Disabilities through Collaborative Consultation." Qualitative Report 17: 1-29.

Welch, M., \& Sheridan, S. M. (1995). Educational partnerships: Serving students at risk. Wadsworth Publishing Company.

Weiner, Howard M. (2003). "Effective Inclusion (Professional Development in Context of the Classroom)". Teaching Exceptional Children Journal, 36, 12-18. 